\title{
The Sociality of Post-truth: Neoliberal Culture and Its Rationality
}

\author{
Debbie Sonu \\ Associate Professor \\ Hunter College \\ City University of New York \\ dsonu@huntersoe.org
}

In her essay, Neoliberalism's Frankenstein, Wendy Brown (2018) unpacks with meticulous depth how the current neoliberal condition valorizes private venture by eroding trust in the meaning of the social. In an attempt to understand, like Michel Foucault (1977), the governing rationality that generates certain kinds of subjects and their conduct, Brown chooses as her object of study the recent hypervisibility of white male right political rage and the inconsequentiality of truth in the context of a liberal "democratic" nation, the United States. With key leaders now legitimizing bigotry as a form of 'greatness', white right rage is given permission to explode onto the scene, crushing political correctness, multiculturalism, plurality and all democratic values, crying liberty and freedom at the helm of hatred and anger. As said by Hannah Arendt (1951), "being right has nothing to do with the objective truthfulness of the Leader's statements which cannot be disproved by facts, but only by future success or failure" (p. 383). Thus, the only reassurance audiences need in a post-truth culture is the constant reassurance that he, the leader, is winning, winning, winning.

For decades, Bruno Latour (2010) has been arguing that even "scientific fact" should be seen as a product of networked culture, robust only when institutions, practices, reliable media uphold its veracity. There is no need for truth here; affective energies are fiercely and more effectively moving. If post-truth signifies an appeal to the emotional drive irrespective of factual or rational truth, how does post-truth emerge and what are the conditions that feed this possibility? What in this society has ignited the affirmation of white nationalism, authoritarian leadership, and the attack on tolerance and inclusion? What role, if any, is there for curriculum studies, teaching and learning, as we consider the future of post-post truth-making that unforeseeably awaits us?

Truth, as a noun, as a fixed absolute, has always been fickle at best. Many in curriculum studies have for a very long time been interested in the potentiality of truth, more specifically in diffracting grand narratives that claim truth through the granular lens of subjective experience, in seeing things "big" as Maxine Greene (1995) would say: the everyday, the performative, the particular, the spectacular and the curious. Even as Peter Seixas (2017) pronounced that "the only threat [to truth] was from some of our own poststructuralist provocateurs, delivered in prose so tortured that it had little apparent impact on the broader public sphere," for us whose livelihoods straddle the tenuous borders of citizenship and otherness, truth has always been a highly contested political project.

History is alit with examples of how post-truthing, or the circulation of fraud, became the very evidentiary narrative used to justify the subjugation of entire groups of people. In 1704, George Psalmanazar, a Frenchman claiming to be born on the island of Formosa, current day Taiwan, published a book in London that became a widespread sensational post-truth about the Orient - people living underground, mass killings of young boys, the presence of gold mines- 
and was even invited by the Bishop of London to teach the Formosan language at Oxford University which he completely fabricated (Keevak, 2004). Scientific racism, race realism, the Bell Curve, evolutionary theory, social Darwinism, are all truth-making attempts employed to justify racial inferiority through practices of classification and order. Former President and founding father of the United States, Thomas Jefferson, renown for his principle of all men being "created equal" was one of the most influential pre-Darwinian evolutionary theorists who called on science to determine Black intellectual inferiority as "nature's distinction" (Kendi, 2016, p. 109). In Stamped from the Beginning, Kendi (2016) brilliantly demonstrates how racist ideas proliferated as post-truths, from its origins in 15th century Europe through colonial times into the current context, as justifications of common sense, by people who claimed to be following God's word, nature's design, or science's plan. Understandably given the disastrous effects of posttruths, any claims of truth are often regarded suspect by those whose very existence has been severed, fragmented, silenced, beaten or murdered by the very same truth that centers dominant groups as somehow more human, more valuable, more whole.

Strangely, the making of truth, as seen above, echoes all too familiarly with the disposal of truth, in both their intention to steer privileges toward the white male right. In line with what Jacques Derrida (1978) said when he claimed, there is no objective truth (it is not that there is no truth!), we need not rely on the illusion of an originary, fixed or stable meaning of truth, but instead attend to the contextual and ideological circumstances that put us in particular relationships with each other and with this truth. Therefore, chasing after what is factually true will be necessary in some cases of outright deceit. While in others, attention should be paid to the ways in which society discursively produces a "regime of truth" (Foucault, 1977) that serves to discipline and govern individuals towards discourses and procedures it accepts and makes function as true. Such truths include questions over: how things are made to appear, how they become represented as normal, and what the conditions are that produce a particular event. As I try to argue, these questions on post-truth and its making must be examined as manifestations of the neoliberal context from which they are borne.

The unbound neoliberal reach and the disintegration of the social are part and parcel to a larger project that seeks to replace the democratic public good with a reconfigured meaning of freedom that is unregulated, individual, and oriented towards profitable ends. Neoliberalism includes not only the unrestricted takeover of public goods by private industries, but also the ways in which the current market system has become the unquestioned, commonsensical governing apparatus. As Brown (2018) remarks, every sphere and human endeavor is economized: "it replaces a model of society based on the justice-producing social contract with society conceived and organized as markets" (p. 62). Key strategies for solidifying neoliberal rationality as human desire and decision include: 1) removing the individual from participating in the social sphere; 2) redefining pleasure from that of leisure to material gain, and 3) establishing an illusion of freedom that justifies inequality and make us complicit to its discriminatory features. In following, the conditions of a post-truth society are inextricably tied to such neoliberal properties and its depressive impact on society and its people. What, then, is the place of curriculum studies in this strange and tenuous moment?

The reconfiguration of nations under neoliberalism has brought heightened apathy and alienation among its citizens (Yuval-Davis, 2011). While in the past, the relationship between the individual and the state was one of general protection from the enemy and the promotion of welfare within, the rise of neoliberalism has shifted this relation to one between the individual 
and the private corporation. According to Nira Yuval-Davis (2011), "the denial of the existence of 'public interest' has also entailed a severe curtailment of 'public responsibility"' (p. 55). The closing of public schools in low-income communities, the vanishing of affordable health care to those in need, the disappearance of small businesses, the rise of multi-national corporations, and the privatization of the prison-industrial complex, are but a few examples of how unfettered business has ushered in a reliance on the private and a distrust, if not a disdain, for the local and social.

In a privatized world that does not see humans as social beings, but rather as extracted data points and potential consumers, there is less need for knowledge, critical thinking, creativity, solidarity or history. Individual conformity to the system via detachment and alienation is precisely the unregulated world in which neoliberalism flourishes. An authentic social life — one that makes room for jouissance of the body ${ }^{1}$ (Cixious \& Calle-Gruber, 1997) and enjoyment in rights and property - is supplanted by the quiet superficialities of online and commodity exchange. Pleasure from leisure, once understood as pleasure outside of work, is now measured by the material possession acquired through a life of unending work. As written by Guy Debord (1967), direct experience is replaced with a stream of representations, "the obvious degradation of being into having... and from having into merely appearing” (p. 17), or social life converted into the accumulation of goods and capital which is then replaced by the sheer spectacle, appearance, or representation of this new unreality. This imbricated life, what he calls a spectacle, presents itself as the society itself, a development that serves to disintegrate social unity and reinforce an exploitative class society. It seems the only reality people are willing to know.

Within this spectacle, current neoliberal rationality delegitimizes federal and state welfare policies aimed to support the very individuals that the white right blame for loss of their racial and economic entitlements and privileges. Thus, they refuse the role of the government in matters of equity and welfare, relying solely on market logic to organize its citizens and establishing competition as the ultimate machine for determining social order. Because freedom is interpreted as only flourishing when there is no human manipulation, social planning and design policies such as universal health care, housing fairness, equitable schools, or reparations are not only undesirable, but also thought dangerous. Policies and practices that aim to redress historical oppression for communities of color, women, immigrants and other subordinated groups, are understood as direct infringements on the deregulated system whose concentration of wealth, held by white male elites, serves to falsely legitimize their superiority and dominance.

It is almost laughable, if not astonishing, that neoliberalism has offered itself as a key to a post-racist world of choice and opportunity. According to Jodi Melamed (2006), market individualism and abstract equality are central tenets of the liberal racial framework in the United States. School choice, which has been lauded as the only available alternative to failing schools in low-income predominantly Black, Latinx and immigrant communities, aims to replace public funding of education with systems of individual vouchers, effectively removing funds from the public sphere into the coffers of charter school proponents who run schools as corporate investments, supplemented by either philanthropic and corporate tax-abated monies. The message is loud and clear: only the market can save our children; the public arena is failing us;

\footnotetext{
${ }^{1}$ In drawing from Helene Cixious, jouissance describes a source of creative power and an empowered voice that emanates from the seat of erotic, mystical and political fusions, a coming to selfhood through the transgression of historically hegemonic patriarchy.
} 
the teacher unions are bad; you have no other choice but ours. The spectacle of neoliberalism, then, appeals to the commonsenses, ensuring by example that the world is reliant on the market for all things life and that there are no other realities for us to work towards. With great insult, the influential economist and free market defender Friedrich Hayek (1960) once wrote: "most of the strictly egalitarian demands are based on nothing better than envy" (p. 156). Such sentiments are echoed by conservative politicians and media pundits, who seized on the opportunity to fuel the flames of anti-immigrant, Islamophobic, racist, misogynistic sentiment already stirring below the surface.

The unsettlement and isolation that arises from individuals who do not feel protected or safe is another aspect of the condition under which authoritarian governments establish their control (Arendt, 1951). This situation may explain the utter disregard for truth in part, but it does not account for the dark rage and bellicosity expressed by those who hit the streets and the Internet with emboldened acts of white supremacy, sexism, racism, xenophobia, and an assault on truth in favor of 'alternative facts.' This is not the first time, of course, that the United States has experienced such rancor by the white right who view their rights as being increasingly threatened by the advancement of non-dominant groups. Recall: threats to poison little Ruby Bridges as she is escorted into her desegregated school; the savage Bloody Sunday beatings following the passage of the 1965 Voting Rights Act; nine church members fallen after a white supremacist shoots up Emanual African Methodist Episcopal Church in downtown, Charleston, South Carolina.

In sum, the making of a neoliberal state, justified by the 'freedom' to live unregulated by the law, but beholden to the function and value of the market system, is not only about privatization. Although privatization is certainly important to combat, more so is the erosion of the social that leaves no theoretical or practical place for human rights or welfare policies and instead uses the accumulation of wealth by white elites as proof of their superiority over other historically subordinated groups. This larger project is the creation of a "personal protected sphere" (Hayek, 1960, p. 140) under rules of "the whole body" (Ahmed, 2014) with capital identified as the lifeblood, "as what must be kept in circulation no matter what (or who)" (p. 105). The degradation of the social has created a sociality that: ensures unfettered individualism and protection from the state; functions in tandem with a disregard for truth and history; and flattens deep inquiry into social context by focusing on short-term gratification, registered in terms of efficiency and sensationalism.

Filled with flashing headlines, trivial soundbites and enticing dramas, we are being ceaselessly bombarded by a barrage of information that rarely accounts for historical depth or breadth. Interestingly, this barrage has served, in part, as an instrument of social cohesion for the country. It is part of the very character of the United States, and there is no better example than the millions of consumerists who descend upon Times Square, New York City to be willfully and joyfully overpowered by a litany of face-melting advertisements and headlines. Neoliberal rationality is the devouring of opposition through the obliteration of the oppositional, the creation of a one-dimensional reality in which we are all complicit, participatory, and then hypocritical (Marcuse, 1964). The central machinery of this reality is largely absent from view, it functions with precision, but the origin of its totality is obscured by its pervasiveness - it being everywhere and nowhere.

Neoliberalism, as a reasoning and rationality, finds its power in the fusion of economic policies and social embodiment. In hooks's remarkable book Killing Rage (1995), she upholds 
her longstanding critique of the "white supremacist capitalist patriarchy" by arguing for greater attention on "the pathology of white supremacy, and the madness it creates" (p. 30). Through the lens of Black feminist thought and always with respect to the context of capitalism, hooks makes it clear that we cannot ignore the structures, systems, and explicit and more implicit ways in which white supremacy has secured protection, not only under this administration, but also through the making of a new economic reality that disintegrates ethical value and legitimizes conservative righteousness.

Of all the scholarly points at which curriculum studies puts pressure, neoliberal society and the disintegration of the social, the reconfiguration of liberty and freedom, and its legitimation of white power all present urgent locations for inquiry and action. Post-truth has emerged amidst this long-standing classist and racist context and it is my hope that by unpacking a few of its major connections, focus is laid not on the chasing of truth (clearly, Trump supporters are not motivated by reason or truth!) but on the logic that organize its condition and the possibility of its revolution.

\section{References}

Ahmed, S. (2014). Willful subjects. Durham, NC: Duke University Press.

Arendt, H. (1951). The origins of totalitarianism. Cleveland, OH: The World Publishing Company.

Brown, W. (2018). Neoliberalism's Frankenstein: Authoritarian freedom in twenty-first century "democracies." Critical Times, 1(1), 60-79.

Cixous, H., \& Calle-Gruber, M. (1997). rootprints: Memory and life writings. London, England: Routledge.

Debord, G. (1967). The society of the spectacle. Paris, France: Buchet-Chastel.

Derrida, J. (1978). Writing and difference. Chicago, IL: University of Chicago Press.

Foucault, M. (1977). Discipline and punish: The birth of the prison. New York, NY: Vintage Books.

Greene, M. (1995). Releasing the imagination: Essays on education, the arts and social change. San Francisco, CA: Jossey-Bass.

Hayek, F. A. (1960). The constitution of liberty. Chicago, IL: The University of Chicago Press. hooks, bell. (1995). Killing rage: Ending racism. New York, NY: Holt Paperbacks.

Keevak, M. (2004). The pretended Asian: George Psalmanazar's eighteenth-century Formosan hoax. Detroit, MI: Wayne State University Press.

Kendi, I. (2016). Stamped from the beginning: The definitive history of racist ideas in America. New York, NY: Nation Books.

Latour, B. (2010, February). Networks, societies, spheres: Reflections of an actor-network theorist. Keynote presented at the International Seminar on Network Theory: Network Multidimensionality in the Digital Age, Annenberg School for Communication and Journalism, Los Angeles. Retrieved from http://www.brunolatour.fr/sites/default/files/121-CASTELLS-GB.pdf

Marcuse, H. (1964). One-dimensional man. Boston. MA: Beacon Press.

Melamed, J. (2006). The spirit of neoliberalism: From racial liberalism to neoliberal multicultural. Social Text, 24(4), 1-24.

Seixas, P. (2017). History educators in a new era. Public History Weekly, 5(20). Retrieved from https://public-history-weekly.degruyter.com/5-2017-20/history-educators-in-a-new-era/

Yuval-Davis, N. (2011). The politics of belonging: Intersectional contestations. London, England: SAGE. 